Gut, 1973, 14, 739-742

\title{
Disturbance of cell-mediated immunity in patients with carcinoma of colon and rectum
}

\author{
O. N. MANOUSOS, J. ECONOMIDOU, CH. PATHOULI, AND G. MERIKAS \\ From the Second Department of Medicine of Athens University, the Hippokration General Hospital, \\ Athens, Greece
}

SUMMARY The cellular immune mechanisms of patients with adenocarcinoma of colon or rectum were evaluated by studying the lymphocyte response to PHA stimulation. Our results indicate that the serum of cancer patients causes a decreased blastic transformation and $\mathrm{H}^{3}$ thymidine uptake of the lymphocytes of patients as well as of normal controls. A defect of the lymphocytes unrelated to serum factors was also present in some cancer patients. However, no relationship was found between the degree of transformation and the presence of metastases in the lymph nodes.

The possible significance of immunological mechanisms in the clinical course of carcinoma of the colon and rectum has been discussed by various authors. As far as local morphological findings are concerned Ackerman (1970) believes that the round cell infiltration around the tumour is an indication of host resistance whereas Willis (1967) considers this phenomenon of no great consequence. Sinus histiocytosis in the lymph nodes draining the tumour is a specific histological phenomenon that has been described in cases of carcinoma of the colon and breast and is believed to represent an immunological reaction (Wartman, 1959; Anastassiades and Pryce, 1966).

Studies of the cell-mediated immunity in groups of patients suffering from various neoplastic diseases Received for publication 10 May 1973. have produced controversial results (table I). In some of these studies patients with carcinoma of coion and rectum have been included and the findings have been discussed together with the results from patients suffering from other neoplastic diseases (Hersh and Oppenheim, 1965; Trubowitz, Masek, and Del Rosario, 1966; Nelson, 1969; Sample, Gertner, and Chretien, 1971).

We have seen occasional patients with sizeable carcinomata of the colon and rectum infiltrating various neighbouring viscera but without causing distal metastases. Resection of these tumours was usually followed by long survival. The common characteristic of these few patients was intense infiltration of the periphery of the tumour by lymphoid and plasmacytic cells. These observations and the lack of precise data in the literature about cell-

\begin{tabular}{|c|c|c|c|}
\hline Author & Type of Neoplastic Disease & Blastic Transformation & Inhibiting Factor \\
\hline Hersh and Oppenheim (1965) & Hodgkin's disease & Reduced & In the lymphocytes \\
\hline Trubowitz et al (1966) & $\begin{array}{l}\text { Hodgkin's disease, lympho- } \\
\text { sarcoma, Chronic lymphatic } \\
\text { leukaemia }\end{array}$ & $\begin{array}{l}\text { Reduced in Hodgkin's disease and } \\
\text { Chronic lymphatic leukaemia }\end{array}$ & $\begin{array}{l}\text { In the plasma of patients with } \\
\text { Hodgkin's disease. In the lympho- } \\
\text { cytes of Chronic lymphatic leukaemia }\end{array}$ \\
\hline Silk (1967) & Various carcinomata & $\begin{array}{l}\text { Plasma from cancer patients } \\
\text { inhibits transformation of control } \\
\text { lymphocytes }\end{array}$ & Plasma of cancer patients \\
\hline Golob et al (1969) & $\begin{array}{l}\text { Various carcinomata } \\
\text { (mainly bronchogenic) }\end{array}$ & Normal & - \\
\hline Nelson (1969) & $\begin{array}{l}\text { Various carcinomata } \\
\text { (mainly brochogenic) }\end{array}$ & Normal & - \\
\hline Al-Sarraf et al (1971) & Various carcinomata & Reduction by heterologous plasma & Heterologous plasma \\
\hline Whittaker et al (1971) & Carcinoma of breast & Reduced & Plasma of cancer patients \\
\hline Sample et al (1971) & Various neoplasms & Reduced & Plasma of patients \\
\hline Lejtenyi et al (1971) & $\begin{array}{l}\text { Various neoplasms of digestive } \\
\text { system }\end{array}$ & Normal & - \\
\hline
\end{tabular}

Table I Published data of PHA-induced lymphocyte transformation in various neoplastic diseases 
mediated immunity in this type of cancer prompted us to make the present study. Our main object was to evaluate the response of the patients' lymphocytes to mitogens and assess the effect of serum factors on PHA-stimulated cultures.

\section{Materials and Methods}

Twenty patients and 19 controls were studied. The patients were suffering from histologically verified adenocarcinoma of colon or rectum. There were 14 men and six women (age range 33-75 years, mean age 63 years). The normal controls were 10 men and nine women (age range 40-72 years, mean age 65 years). Special care was taken to include patients in good general condition without evidence of cutrent infection; no chemotherapy or radiotherapy had been given to the patients. The study was performed preoperatively in order to avoid the possible immunosuppressive effect of surgery (Park, Brody, Wallace, and Blakemore, 1971).

In each patient the response of the lymphocytes to PHA stimulation was studied in the presence of his own serum and in that of serum from a normal control of the same blood group. The lymphocytes of the normal controls were studied in the presence of their own serum and in the presence of serum from a cancer patient of the same blood group. Each lymphocyte culture was set up in duplicate; the degree of blastic transformation was assessed by studying the morphology of the cells and the incorporation of $\mathrm{H}^{3}$ thymidine into DNA by autoradiography.

\section{CULTURE OF LYMPHOCYTES}

White cells were separated from venous heparinized blood by sedimentation at $37^{\circ} \mathrm{C}$. After washing the cell pellet with TC medium 199 (Difco) twice and allowing the polymorphonuclear cells to sediment by gravity, white cell suspensions were obtained containing 40 to $70 \%$ lymphocytes.

To each duplicate culture tube 1.5-2 $\times 10^{6}$ lymphocytes in $2.0 \mathrm{ml}$ of TC medium containing
200 I Units of penicillin and $200 \mu \mathrm{g}$ of streptomycin/ $\mathrm{ml}$ were added. To each tube $0.5 \mathrm{ml}$ of either fresh autologous serum or serum from another subject of the same ABO group was added. Finally $0.05 \mathrm{ml}$ of PHA-M Difco was introduced as a stimulant. The culture tubes were incubated at $37^{\circ} \mathrm{C}$ for 72 hours. To one of the duplicate tubes used for autoradiography $0.5 \mu \mathrm{C}{ }^{3} \mathrm{H}$-thymidine for each millilitre of culture fluid was added four hours before harvesting.

At the end of the 72 hours all the tubes were centrifuged at $1000 \mathrm{rpm}$ for 10 minutes. The supernatant was discarded; in order to obtain good smears a few drops of a solution containing red cells of blood group $\mathrm{O}$ in $\mathrm{AB}$ serum were added to the sediment. After thorough mixing and disintegration of the cell clumps, smears were prepared. The smears were either stained with May Grünwald-Giemsa or were processed for autoradiography. In order to estimate the percentage of blastic transformation 500 cells were counted from each preparation and the mitotic blastic and intermediate forms were recorded.

\section{AUTORADIOGRAPHY}

The preparations were fixed by immersion in three successive solutions of methyl alcohol for five minutes. Autoradiography film Kodak AR 10 was used.

After exposure for two weeks at $4^{\circ} \mathrm{C}$ the usual processing (Paul, 1965) was carried out and the smears were stained with Leishman-Giemsa for $\mathbf{3 0}$ minutes. From each preparation 500 lymphoid cells were counted and the numbers of cells containing radioactive thymidine were recorded.

\section{Results}

The results of the morphological and autoradio graphic study are shown in table II.

The highest degree of blastic transformation occurred in the lymphocytes of normal subjects cultured in the presence of their own serum (mean value $73.0 \%$ ) and the smallest in the cultures of

\begin{tabular}{|c|c|c|c|c|c|}
\hline \multirow[t]{3}{*}{ Material } & \multirow[t]{3}{*}{ No. of Subjects Studied } & \multicolumn{2}{|l|}{ Morphology } & \multicolumn{2}{|c|}{ Autoradiography } \\
\hline & & \multicolumn{2}{|c|}{ Blastic Transformation (\%) } & \multicolumn{2}{|c|}{${ }^{8} \mathrm{HT}$ Uptake (\%) } \\
\hline & & Mean Values & $S D$ & Mean Values & $S D$ \\
\hline $\begin{array}{l}\text { Patients' lymphocytes } \\
\text { In the presence of patients' serum } \\
\text { In the presence of control serum }\end{array}$ & $\begin{array}{l}20 \\
20\end{array}$ & $\begin{array}{l}56 \cdot 4 \\
63 \cdot 1\end{array}$ & $\begin{array}{l}22.9 \\
22.7\end{array}$ & $\begin{array}{l}14 \cdot 1 \\
13 \cdot 5\end{array}$ & $\begin{array}{r}10 \cdot 0 \\
8.2\end{array}$ \\
\hline $\begin{array}{l}\text { Control lymphocytes } \\
\text { In the presence of control serum } \\
\text { In the presence of patients' serum }\end{array}$ & $\begin{array}{l}16 \\
19\end{array}$ & $\begin{array}{l}73 \cdot 0 \\
65.6\end{array}$ & $\begin{array}{l}14 \cdot 8 \\
21 \cdot 2\end{array}$ & $\begin{array}{l}23 \cdot 3 \\
18 \cdot 3\end{array}$ & $\begin{array}{l}10 \cdot 2 \\
10 \cdot 3\end{array}$ \\
\hline
\end{tabular}

Table II Results of lymphocyte culture (patients with carcinoma of colon or rectum and controls) 


\begin{tabular}{|c|c|c|c|c|}
\hline \multirow[t]{2}{*}{ Groups Tested } & \multicolumn{2}{|c|}{ Blastic Transformation } & \multicolumn{2}{|c|}{ Autoradiography } \\
\hline & $t$ & $p$ & $t$ & $p$ \\
\hline
\end{tabular}

Table III Statistical analysis of the results of lymphocyte cultures

lymphocytes of the cancer patients cultured in their serum (mean values $56.4 \%$ ). The uptake of ${ }^{3} \mathrm{H} \mathrm{T}$ as evaluated by autoradiography followed essentially a similar pattern. The statistical analysis of the results (table III) points to the following conclusions:(1) The lymphocytes of normal controls cultured with their own serum show a significantly higher degree of blastic transformation than the lymphocytes of cancer patients cultured in the presence of their serum. (2) Lymphocytes from normal controls show significantly higher degrees of transformation when cultured with their serum than when serum from cancer patients is present. (3) The degree of transformation of the lymphocytes of cancer patients was about the same whether they were cultured in the presence of their own serum or serum from normal controls.

The results of lymphocyte culture were correlated with the presence of metastases in the regional lymph nodes (table IV). Metastatic cancer was present in 14 of the 20 cases. In nine of the 14, the degree of blastic transformation was above $60 \%$ and only in three was it below $40 \%$.

\begin{tabular}{|c|c|c|c|}
\hline Case No. & $\begin{array}{l}\text { Blastic } \\
\text { Transformation (\%) }\end{array}$ & $\begin{array}{l}\text { 'H Thymidine } \\
\text { Uptake }(\%)\end{array}$ & $\begin{array}{l}\text { Lymph Node } \\
\text { Metastases }\end{array}$ \\
\hline 1 & 78 & 20 & + \\
\hline 2 & 60 & 3 & + \\
\hline 3 & 60 & 19 & + \\
\hline 4 & 44 & 15 & + \\
\hline 5 & 20 & 0 & - \\
\hline 6 & 80 & 34 & + \\
\hline 7 & 84 & 20 & - \\
\hline 8 & 62 & 22 & - \\
\hline 9 & 76 & 24 & + \\
\hline 10 & 52 & 7 & + \\
\hline 11 & 39 & 7 & + \\
\hline 12 & 76 & 28 & + \\
\hline 13 & 8 & 0 & - \\
\hline 14 & 63 & 14 & + \\
\hline 15 & 56 & 11 & - \\
\hline 16 & 75 & 17 & - \\
\hline 17 & 13 & 0 & + \\
\hline 18 & 37 & 2 & + \\
\hline 19 & 75 & 18 & + \\
\hline 20 & 71 & 22 & + \\
\hline
\end{tabular}

Table IV Results of lymphocyte culture of cancer patients in the presence of own serum with reference to the presence or absence of metastases in the regional lymph nodes

\section{Discussion}

The main finding of the present study was that the mean values of blastic transformation of the lymphocytes of cancer patients cultured in their own serum were significantly smaller than the values obtained from the culture of control lymphocytes cultured in their serum. This suggests that the lymphocytes of the cancer patients in their natural environment show a decreased response to the mitogenic factor PHA. The next finding that the stimulation of normal lymphocytes is suppressed by the serum from cancer patients supports the view that an agent responsible for the decreased transformation resides in the serum of the cancer patients; however, the finding that lymphocytes from cancer patients cultured in control serum do not show significant improvement in the degree of transformation suggests that there must also be an inherent defect in the lymphocytes. Although the number of patients studied was relatively small the fact that the patients were in relatively good condition and had not received any treatment that might be considered immunosuppressive adds strength to these findings. Also, in order to have the best possible conditions for comparison, the controls used were of the same age groups as the patients (Pisciotta, Westring, DePrey, and Walsh, 1967).

According to current ideas, decreased blastic transformation of lymphocytes in the presence of PHA is taken as an indication of decreased cellmediated immunity (Roitt, Torrigiani, Greaves, Brostoff, and Playfair, 1969). The mechanisms of this decreased blastic transformation are unknown. Recently it was suggested that the decreased rate of blastic transformation of lymphocytes of pregnant women may be due to the circulating carcinoembryonic antigen (CEA) which is believed to cover specific receptors on the surface of the maternal lymphocytes (Purtilo, Hallgren, and Yunis, 1972). If this explanation is correct it could easily be applicable to our patients whose sera are expected to contain large amounts of CEA.

Studies of lymphocyte transformation in the presence of PHA have been made in various neoplastic diseases and the results are controversial 
(table I). The discrepancies reported might be due to some extent to differences in methodology. Another factor is probably that results obtained from the study of various neoplastic diseases have been discussed together (Golob, Israena, Quatrale, and Becker, 1969; Al-Sarraf, Sardesai, and Vaitkevicius, 1971) on the assumption that whatever immunological disturbance occurs in one neoplastic disease should be present in other neoplasias, a conclusion which does not seem to be justified. In a study of patients suffering from carcinoma of the breast on the one hand and benign breast disease on the other, it was clearly shown that the inhibiting factor was present in the serum of the cancer patients (Whittaker, Rees, and Clark, 1971). As far as carcinoma of the colon and rectum is concerned the evidence in the literature is confusing. Silk (1967) in his study included three patients with carcinoma of the colon and found that the mean rate of blastic transformation of these patients was smaller than the mean rate of transformation of five patients suffering from carcinoma of the prostate. Lejtenyi, Freedman, and Gold (1971) studied the rate of blastic transformation of lymphocytes from patients suffering from various gastrointestinal carcinomata in the presence of CEA. For purposes of comparison they studied the blastic transformation of the lymphocytes of patients and controls in the presence of PHA and found no difference. The difference between those findings and our results might be due to the fact that these authors included carcinomata from all parts of the digestive tract. In more than half of our cases with demonstrable lymph node metastases (table IV) the degree of blastic transformation was above $60 \%$ which is within 1 SD of the mean normal control values. This finding supports the view put forward by Stewart (1969) that normal cellmediated immunity does not necessarily mean a good prognosis. This apparent paradox can be explained by the experimental findings of Hellström, Hellström, Pierce, and Young (1968) and Hellström, Sjögren, Warner, and Hellström (1971). These authors observed that the plating efficiency of neoplastic cells in culture was inhibited by the presence of the patients' lymphocytes and that the addition of the patients' serum cancelled this antitumour effect of the lymphocytes. So in certain (or all?) cancer patients it appears that there is an interplay between cellular reactions mediated by lymphocytes and serum factors (enhancing antibody) antagonizing the cell reaction of the host.

References

Ackerman, L. V. (1970). In Cancer, 4th ed., edited by L. V. Ackerman and J. Del Regato, p. 484, Mosby, St. Louis.

Al-Sarraf, M., Sardesai, S., and Vaitkevicius, V. K. (1971). Effect of syngeneic and allogeneic plasma on lymphocytes from cancer patients, patients with non-neoplastic diseases and normal subjects. Cancer (Philad.), 27, 1426-1432.

Anastassiades, O., and Pryce, D. M. (1966). Immunological significance of the morphological changes in lymph nodes draining breast cancer. Brit. J. Cancer, 20, 239-249.

Golob, E. K., Israena, T., Quatrale, A. C., and Becker, K. L. (1969.) Effect of serum from cancer patients on homologous lymphocyte cultures. Cancer (Philad.), 23, 306-308.

Hellström, I., Hellström, K. E., Pierce, G. E., and Yang, J. P. S. (1968). Cellular and humoral immunity to different types of human neoplasms. Nature (Lond.), 220, 1352-1354.

Hellström, I., Sjögren, H. O., Warner, G., and Hellström, K. E. (1971). Blocking of cell-mediated tumor immunity by sera from patients with growing neoplasms. Int. J. Cancer, 7, 226-237.

Hersh, E. M., and Oppenheim, J. J. (1965). Inhibition of in vitro lymphocyte transformation during chemotherapy in man. Proc. Amer. Ass. Cancer Res., 6, 27-32.

Lejtenyi, M. C., Freedman, S. O., and Gold, P. (1971). Response of lymphocytes from patients with gastrointestinal cancer to the carcinoembryonic antigen of the human digestive system. Cancer (Philad.), 28, 115-120.

Nelson, H. S. (1969). Delayed hypersensitivity in cancer patients: Cutaneous and in vitro lymphocyte response to specific antigens. J. nat. Cancer Inst., 42, 765-770.

Park, S. K., Brody, J. I., Wallace, H. A., and Blakemore, W. S. (1971). Immunosuppressive effect of surgery. Lancet, 1, 53-55.

Paul, J. (1965). Cell and Tissue Culture, p. 916. Livingstone, Edinburgh and London.

Pisciotta, A. V., Westring, D. W., DePrey, C., and Walsh, B. (1967). The mitogenic effect of phytohaemagglutinin at different ages. Nature (Lond.), 215, 193-194.

Purtilo, D. T., Hallgren, H. M., and Yunis, E. J. (1972). Depressed maternal lymphocyte response to phytohaemagglutinin in human pregnancy. Lancet, 1, 769-771.

Roitt, I. M., Torrigiani, G., Greaves, M. F., Brostoff, J., and Playfair, J. H. L. (1969). The cellular basis of immunological responses. Lancet, 2, 367-371.

Sample, W. F., Gertner, H. R., Jr., and Chretien, P. B. (1971). Inhibition of phytohemagglutinin induced in vitro lymphocyte transformation by serum from patients with carcinoma. J. nat. Cancer Inst., 46, 1291-1297.

Silk, M. (1967). Effect of plasma from patients with carcinoma on in vitro lymphocyte transformation. Cancer (Philad.), 20, 20882089.

Stewart, T. H. M. (1969). The presence of delayed hypersensitivity reactions in patients toward cellular extracts of their malignant tumors. Cancer (Philad.), 23, 1368-1379.

Trubowitz, S., Masek, B., and Del Rosario, A. (1966). Lymphocyte response to phytohemagglutinin in Hodgkin's disease, lymphatic leukemia and lymphosarcoma. Cancer (Philad.), 19, 2019-2023.

Wartman, W. B. (1959). Sinus cell hyperplasia of lymph nodes regional to adenocarcinoma of the breast and colon. Brit. J. Cancer, 13, 389-397.

Whittaker, M. G., Rees, K., and Clark, C. G. (1971). Reduced lymphocyte transformation in breast cancer. Lancet, 1, 892-893.

Willis, R. A. (1967). Pathology of Tumours, 4th ed., p. 457. Butterworth, London. 